\title{
Procalcitonin Levels in Migraine Patients
}

\author{
Hale Turan, Bahriye Horasanli, Murat Ugur, Hande Arslan
}

\begin{abstract}
Objectives: Migraine is a risk factor for ischemic stroke. Sterile vascular inflammation may develop during migraine attacks. This study aims to investigate procalcitonin (PCT) levels amongst migraine patients as they are important markers for infection and sepsis, but can also be found at elevated levels in various cases of inflammation. Methods: Eighty adult migraine patients participated in our study. Patients were initially separated into two main groups; Group-1 consisted of 34 patients who had migraines during the attack period. Group- 2 consisted of 46 patients during the period in-between attacks. Afterwards, patients were further divided into four subgroups based on their aura status; Group-1a Migraine without aura, 27 patients during attack period, Group-1b Migraine with aura, 7 patients during attack period, Group-2a Migraine without aura, 40 patients during the period in-between attacks, Group-2b Migraine with aura, 6 patients during the period in-between attacks. Results: Average PCT levels in patients during attack periods were found to be higher than the average PCT levels of patients during the period in-between attacks. These elevated levels were determined to be statistically significant $(\mathrm{p}<0.01)$. Serum PCT levels of the patients with migraine without aura during the attack period were significantly higher than those of patients during the period in-between attacks $(\mathrm{p}<0.01)$. Conclusions: Based on significantly high levels of PCT, our results support the idea that sterile inflammation plays a role in migraine pathogenesis. Further studies are necessary to understand whether PCT is a marker for ischemic stroke risk in patients who go through frequent migraine attacks.
\end{abstract}

RÉSUMÉ: Niveau de procalcitonine chez les patients migraineux. Objectifs : La migraine est un facteur de risque de l'accident vasculaire cérébral ischémique. Une inflammation vasculaire stérile peut survenir pendant les crises de migraine. Le but de cette étude était de déterminer chez des patients migraineux les niveaux de procalcitonine (PCT), un marqueur important de l'infection et de la septicémie, qui peut également être élevé dans l'inflammation due à des causes variées. Méthodes : Quatre-vingt patients migraineux adultes ont participé à notre étude. Les patients ont été répartis en deux groupes : dans le groupe 1, composé de 34 patients, le taux de PCT était mesuré pendant les crises ; dans le groupe 2, composé de 46 patients, le taux de PCT était mesuré entre les crises. Chaque groupe était ensuite subdivisé en deux sous-groupes selon l'absence ou la présence d'une aura : le groupe 1a, composé de 27 patients sans aura et le groupe 1b, composé de 7 patients avec aura; le groupe $2 \mathrm{a}$, composé de 40 patients sans aura et le groupe $2 \mathrm{~b}$, composé de 6 patients avec aura. Résultats : Les taux moyens de PCT mesurés pendant les crises étaient plus élevés que les taux moyens mesurés entre les crises et la différence était significative au point de vue statistique $(\mathrm{p}<0,01)$. Les niveaux sériques de PCT des patients avec migraine sans aura étaient significativement plus élevés pendant les crises qu'entre les crises $(\mathrm{p}<0,01)$. Conclusions : Nos résultats, soit des taux significativement plus élevés de PCT, sont en faveur de l'hypothèse selon laquelle l'inflammation stérile jouerait un rôle dans la pathogenèse de la migraine. Il faudra des études plus poussées pour déterminer si la PCT est un marqueur du risque d'accident vasculaire cérébral chez les patients dont les crises de migraine sont fréquentes.

Can. J. Neurol. Sci. 2011; 38: 124-128

Migraine is a risk factor for stroke, especially in women who have migraine with aura ${ }^{1}$. The underlying mechanism of coexistence between migraine and cerebrovascular disease is unknown ${ }^{2}$. After a series of experiments, Moskowitz and Cutrer have found results suggesting that migraine pain is a type of sterile inflammation ${ }^{3}$. In migraine models today, presence of neurogenic inflammation is shown and triptans which are effective therapeutic drugs are used to block neurogenic inflammation ${ }^{4}$. During migraine attacks, there might be sterile inflammation in cerebral and extra-cerebral vessels ${ }^{5}$. It is thought that neural activation due to inflammation in particular brain tissues and the release of proinflammatory neuropeptides from perivascular neuron endings are the cause of migraine attacks $^{6}$. In the vascular system, it has been described that inflammatory process plays an important role in ischemic stroke pathogenesis ${ }^{7}$. Recurring episodes of perivascular inflammation during migraine attacks can increase the risk of stroke ${ }^{8}$.
In migraine patients, there are studies showing elevated levels of C-Reactive Protein (CRP) which is an indicator of inflammation ${ }^{2,9}$. C-Reactive Protein is a marker for active systemic inflammation, oxidative stress and risk of stroke ${ }^{10,11}$.

From the Department of Infectious Diseases and Clinical Microbiology Department (HT), Neurology Department (BH), Emergency Department (MU), Baskent University Faculty of Medicine, Selçuklu, Konya; Department of Infectious Diseases and Clinical Microbiology (HA), Bahçelievler, Ankara, Turkey.

Received June 15, 2010. Final Revisions Submitted August 11, 2010. Correspondence to: Hale Turan, Baskent University Faculty of Medicine, Department of Infectious Diseases and Clinical Microbiology Department, Hocacihan mahallesi. Saray caddesi No:1, Selçuklu 42080, Konya, Turkey. 
Table 1: Characteristics of study participants

\begin{tabular}{|c|c|c|}
\hline & Group 1 (n:34) & Group 2 (n:46) \\
\hline Age, mean (SD), years & $38.5 \pm 7.6$ & $33.8 \pm 7.0$ \\
\hline Gender (female/male) & $25 / 9$ & $37 / 9$ \\
\hline Body Mass Index, mean (SD), $\mathrm{kg} / \mathrm{m}^{2}$ & $22.7 \pm 2.8$ & $21.9 \pm 3.0$ \\
\hline \multicolumn{3}{|l|}{ Blood pressure, mean (SD), $\mathrm{mmHg}$} \\
\hline Systolic & $119(7)$ & $117(5)$ \\
\hline Diastolic & $62(3)$ & $66(3)$ \\
\hline \multicolumn{3}{|l|}{ Cholesterol, mean (SD), mg/dL } \\
\hline Total & $158 \pm 16$ & $161 \pm 17$ \\
\hline High-density lipoprotein & $51 \pm 6$ & $49 \pm 8$ \\
\hline Low-density lipoprotein & $76 \pm 15$ & $86 \pm 19$ \\
\hline Triglycerides, mean (SD), mg/dL & $99 \pm 22$ & $101 \pm 27$ \\
\hline
\end{tabular}

Identified in recent years, Procalcitonin (PCT) is a highly sensitive and specific marker that is used in early diagnosis of bacterial infections and follow-up treatments. It was reported that PCT can increase independent of infectious situations such as burns, trauma, surgical attempts and cardiogenic shock ${ }^{12}$. Procalcitonin may be a possible prognostic factor in acute stroke $^{13}$.

Our study will be the first report in the literature that determines PCT levels of migraine patients. Our goal in this study is to determine PCT levels, which are also an indicator of inflammation in migraine patients with and without aura, especially during attack periods.

\section{Materials And Methods}

Eighty adult patients with migraine who were admitted to the neurology or emergency outpatient clinics in our university hospital between November 2008 and April 2009 participated in our study. Of these patients, 34 were in the migraine attack period, and 46 were in the period in-between attacks. Patients underwent neurological examinations by a neurology specialist; anamnesis and physical examinations findings were recorded.
Migraine with or without aura diagnosis was determined based on The International Headache Society classification ${ }^{14}$. Patients who were under 18 and over 45 years-of-age, with body mass index less then 18 or over 30; had cardiovascular disease, hypertension, history of hypercholesterolemia, smoking, using oral contraceptive medication, and those who were pregnant or lactating were not included in the study. Patients diagnosed with migraine for less than one year and more than six years, cases receiving prophylactic treatment or those who had headaches for more than 15 days each month were excluded from the study. Patients were allowed to use drugs specific or non-specific for migraine.

All patients were informed before participating in the study and all of them signed voluntary consent forms. Blood samples were taken from patients during the in-between attack period at least 72 hours after the last attack. Samples were drawn within 12 hours from patients that were in the attack period. The serum samples from the patients were stored at $-40{ }^{\circ} \mathrm{C}$ until PCT test was conducted.

Procalcitonin measurement was made using B.R.A.H.M.S sensitive Procalcitonin Kryptor kit in the Kryptor immunoassay

Table 2: Procalcitonin levels in groups and subgroups

\begin{tabular}{|c|c|c|c|c|}
\hline \multirow{2}{*}{ Procalcitonin ng/mL } & \multicolumn{2}{|c|}{$\begin{array}{c}\text { Group } 1 \\
\text { (Patients during attack period) } \\
\mathrm{n}: 34 \\
0.0485 \pm 0.035^{*}\end{array}$} & \multicolumn{2}{|c|}{$\begin{array}{c}\text { Group } 2 \\
\text { (Patients during interictal period) } \\
\mathrm{n}: 46 \\
0.0298 \pm 0.014^{*}\end{array}$} \\
\hline & $\begin{array}{c}\text { Group } 1 \mathrm{a}^{\dagger} \\
\mathrm{n}: 27 \\
0.0493 \pm 0.03\end{array}$ & $\begin{array}{c}\text { Group 1b } \\
\mathrm{n}: 7 \\
0.0457 \pm 0.02\end{array}$ & $\begin{array}{c}\text { Group } 2 \mathrm{a}^{\dagger} \\
\mathrm{n}: 40 \\
0.0285 \pm 0.01\end{array}$ & $\begin{array}{c}\text { Group } 2 \mathrm{~b} \\
\mathrm{n}: 6 \\
0.0383 \pm 0.01\end{array}$ \\
\hline
\end{tabular}

*Group 1 compared to Group 2: $\mathrm{p}<0.01$; $\dagger$ Group 1a compared to Group 2a: $\mathrm{p}<0.01$; Group 1a and 2a: Patients without aura 
machine which uses immunoflourescence TRACE (Time Resolved Amplified Cryptate Emission) technology. (BrahmsDiagnostica, Henningsdorf, Germany).

Data were analyzed using the Statistical Package for the Social Sciences, version 13.0 (SPSS, Chicago, Illionis, USA). Student's t-test, one way analysis of variance test and linear regression analysis were used for statistical analyses. Values $\mathrm{p}<0.01$ was taken as the criterion of statistical significance.

\section{RESULTS}

None of the patients had signs of active infection. As the antimigraine treatment, 50 of the patients $(62.5 \%)$ received analgesic treatment, $10(12.5 \%)$ received triptan therapy and $20(23 \%)$ did not receive any treatment.

The patients were divided into two groups. Those who had migraines during attack period (34 patients) were assigned to Group 1, and those who had migraines during the period inbetween attacks (interictal) (46 patients) were in Group 2. Clinical characteristics of the study participants are shown in Table 1.

The average PCT level of patients during the attack period $(0.0485 \pm 0.035)$ was found to be higher than the average PCT levels of patients during the period in-between attacks $(0.0298 \pm 0.04)$. The high levels were found to be statistically significant $(\mathrm{p}<0.01)$ (Table 2$)$.
Patient grouping was made based on the aura status; the groups were further divided into two sub-groups:

Group 1a. Migraine without aura, attack period, $\mathrm{n}=27$ (average age $=37.6 \pm 8 ; 22$ females, 5 males).

Group 1b. Migraine with aura, attack period, $n=7$ (average age $=41.7 \pm 4 ; 3$ females, 4 males).

Group 2a. Migraine without aura, interictal period, $n=40$ (average age $=33.3 \pm 7 ; 33$ females, 7 males).

Group 2b. Migraine with aura, interictal period, $\mathrm{n}=6$ (average age $=37.5 \pm 3,4$ females, 2 males).

Average PCT levels from the subgroups of migraine patients are shown in Table 2. When migraine subgroup distinction was made, serum PCT levels of patients during attack period were significantly higher than those of migraine patients without aura during interictal period $(\mathrm{p}<0.01)$. There were no significant difference in serum PCT levels between other groups $(\mathrm{p}>0.01)$. (Figure)

\section{Discussion}

As a result of a series of experiments, Moskowitz and colleagues have obtained results that suggested migraine pain is a type of sterile inflammation ${ }^{3}$. Waeber and colleagues have stressed that ions, free radicals, complement system, kinines and cytokines are important in the inflammatory process ${ }^{6}$. C-

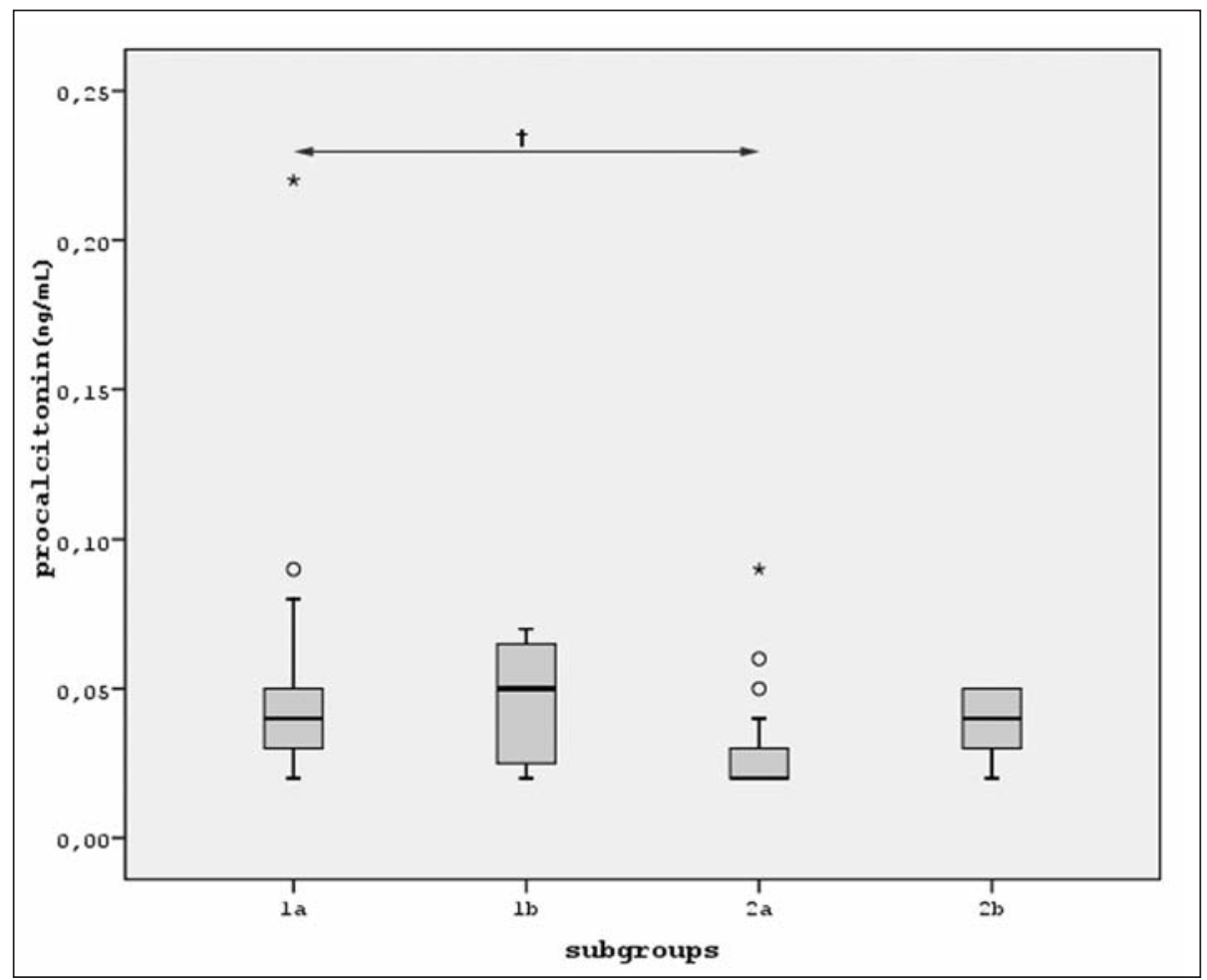

Figure: Evolution of serum procalcitonin (PCT) levels in patients with migraine, as well as serum PCT levels for the patients of the study. Group 1a: Migraine without aura during attack period. Group 1b: Migraine with aura during attack period. Group 2a: Migraine without aura, during the interictal period. Group 2b: Migraine with aura, during the interictal period. Results are depicted as median (bold horizontal line), 25th-75th percentiles (box) and 90th percentiles (plot lines). Cases that are outliers (with values between 1.5 and 3 box lengths from the upper edge of the box) are represented with circles (O), whereas extremes (cases with values more than 3 box lengths from the upper edge of the box) are illustrated as asterisks (*).

+ Compared with two subgroups: $p<0.01$ 
Reactive Protein is a marker for active systematic inflammation, oxidative stress and stroke risk ${ }^{10,11}$. There are studies showing elevated levels of CRP in patients with migraine ${ }^{2,9}$. In the first one of these studies, CRP levels in-between attack period was studied $^{2}$, in the second one CRP levels of migraine patients during attack period was studied ${ }^{9}$. In our study, we evaluated PCT values from cases in both periods.

Serum PCT levels may be very high in patients with inhalational injury, burn injury, mechanical trauma, extensive surgery or heatstroke. Although bacterial infection may be absent in these conditions, the PCT levels attained may not differ very much from many of the levels seen in sepsis ${ }^{12}$.

In case of infection, many indicators develop in the body in response to the infection. Among these, CRP is quite a sensitive indicator of inflammation. However, it cannot distinguish between bacterial and non-bacterial infections since CRP levels also increase significantly due to surgery, trauma, malignancies, autoimmune diseases, and chronic inflammatory diseases ${ }^{15}$. CReactive Protein elevation is a predefined marker for risk of stroke in patients with atherosclerotic cerebrovascular disease ${ }^{11,16}$. In addition, increased serum CRP levels are associated with the presence and progression of white matter lesions in patients with cerebral small-vessel disease ${ }^{17}$. Reasonably established in patients as the basis for migraine aura, spreading cortical depression in experimental models causes oxidative stress, leukocyte activation, and inflammatory dilation of extra-parenchymal vessels mediated by trigeminal peptide release $^{18}$. Migraine without aura may have the same inflammatory basis. C-Reactive Protein is associated with oxidative stress and inflammatory mechanisms in blood vessels, and in itself may contribute to atherogenesis and a procoagulant state $^{19}$. In previous studies, CRP levels in migraine without aura patients were determined to be significantly higher than normal levels ${ }^{2,9}$. In both studies, high CRP levels in migraine without aura patients could not be explained. In a recent study, Gudmundsson and colleagues have reported that women with migraineurs without aura had higher CRP values than normal level in the young age group (19-34 years) ${ }^{20}$. We detected elevated levels of another inflammation marker, serum PCT, in patients with migraine without aura during attack periods. This finding supports studies showing elevated CRP values in patients with migraine without aura.

Serum CRP is an established inflammatory risk marker for ischaemic stroke $\mathrm{e}^{21}$ and coronary heart disease ${ }^{19}$. There are also studies related to the role of PCT in coronary artery disease and acute stroke ${ }^{13,16}$. Some authors report increased levels of PCT in acute coronary syndrome patients ${ }^{16,22}$. As a result of their study with 30 stroke patients, Miyakis and colleagues have reported that serum PCT cannot be a candidate marker for prognosis of stroke $^{13}$.

Calcitonin gene-related peptide (CGRP)-containing nerves are closely associated with cranial blood vessels. Calcitonin gene-related peptide is the most potent vasodilator known in isolated cerebral blood vessels. Calcitonin gene-related peptide can induce migraine attacks, and two selective CGRP receptor antagonists are effective in the treatment of migraine attacks ${ }^{23}$. Intravenous administration of CGRP causes headache and migraine in migraineurs, suggesting that the increase in CGRP observed during spontaneous migraine attacks may play a causative role ${ }^{24}$. Procalcitonin is the precursor of the hormone calcitonin. Production is governed by the Calc-1 gene, located on chromosome 11. Calc-1 codes for preprocalcitonin which undergoes proteolytic cleavage of its signal sequence to produce PCT. Alternative splicing of the mRNA from Calc-1 leads to the generation of CGRP, a powerful vasodilator mainly found in the central nervous system. Similar to PCT, CGRP synthesis is also increased in sepsis, although to lower concentration ${ }^{25,26}$. In our study, we found significantly high levels of PCT in patients with migraine during the attack period. As a result, we can state that there might be an increase in PCT levels in addition to CGRP increase, in migraine patients similar to sepsis patients.

\section{Conclusions}

Based on our results, we can state that PCT is a more distinguishing marker for migraine attacks. These high PCT levels are parallel to Moskowitz and Cutrer's ${ }^{3}$ findings which suggest that migraine pain is a type of sterile inflammation. Our results support that inflammation plays a role in acute migraine attacks. Although no prognostic effect was shown in patients with stroke ${ }^{13}$, further studies are necessary to find an answer to the question of whether PCT is a marker for risk of stroke in migraine patients.

\section{REFERENCES}

1. Bousser MG, Welch KM. Relation between migraine and stroke. Lancet Neurol. 2005;4:533-42.

2. Vanmolkot FH, de Hoon JN. Increased C-reactive protein in young adult patients with migraine. Cephalalgia. 2007;27:843-6.

3. Moskowitz MA, Cutrer FM. Sumatriptan: a receptor-targeted for migraine. Ann Rev Med. 1993;44:145-54.

4. Buzzi MG, Moskowitz MA. The antimigraine drug, sumatriptan (GR43175) selectively blocks neurogenic plasma extravasation from blood vessels in dura mater. Br J Pharmacol. 1990;99: 202-6.

5. Bolay H, Reuter U, Dunn AK, Huang Z, Boas DA, Moskowitz MA. Intrinsic brain activity triggers trigeminal meningeal afferents in a migraine model. Nat Med. 2002;8:136-42.

6. Waeber C, Moskowitz MA. Migraine as an inflammatory disorder. Neurology. 2005;64:9-15.

7. Lindsberg PJ, Grau AJ. Inflammation and infections as risk factors for ischemic stroke. Stroke. 2003;34:2518-32.

8. Welch KM. Stroke and migraine-the spectrum of cause and effect. Funct Neurol. 2003;18:121-6.

9. Welch KM, Brandes AW, Salerno L, Brandes JL. C-reactive protein may be increased in migraine patients who present with complex clinical features. Headache. 2006;46:197-9.

10. Yasunari K, Maeda K, Nakamura M. Oxidative stress in leukocytes is a possible link between blood pressure, blood glucose, and Creactive protein. Hypertension. 2002;39:777-80.

11. Ridker PM, Cushman M, Stampfer MJ, Tracy RP, Hennekens CH. Inflammation, aspirin, and the risk of cardiovascular disease in apparently healthy men. N Eng J Med. 1997;336:973-9.

12. Becker KL, Snider R, Nylen ES. Procalcitonin assay in systemic inflammation, infection, and sepsis: clinical utility and limitations. Crit Care Med. 2008;36(3):941-52.

13. Miyakis S, Georgakopoulos P, Kiagia M, et al. Serial serum procalcitonin changes in the prognosis of acute stroke. Clin Chim Acta. 2004;350:237-9.

14. Headache Classification Committee of the International Headache Society. Classification and diagnostic criteria for headache disorders, cranial neuralgias and facial pain. Cephalalgia. 1988; 8:1-96.

15. Johnson AM, Rohlfs EM, Silverman LM. Proteins. In: Burtis CA, Ashwoodd ER, editors. Tietz textbook of clinical chemistry. Philadelphia: WB Saunders; 1999. p. 493. 
16. Biasucci LM, Biasillo G, Stefanelli A. Procalcitonin and acute coronary syndromes; a new biomarker for an old disease. Intern Emerg Med. 2009;4:363-5.

17. van Dijk EJ, Prins ND, Vermeer SE, et al. C-reactive protein and cerebral small-vessel disease: the Rotterdam Scan Study. Circulation. 2005; 112:900-5.

18. Choudhuri R, Cui L, Yong C, et al. Cortical spreading depression and gene regulation: relevance to migraine. Ann Neurol. 2002; 51:499-506.

19. Pearson TA, Mensah GA, Alexander RW, et al. Markers of inflammation and cardiovascular disease: application to clinical and public health practice: a statement for healthcare professionals from the Centers for Disease Control and Prevention and the American Heart Association. Circulation. 2003;107:499-511.

20. Gudmundsson LS, Aspelund T, Scher AI, et al. C-reactive protein in migraine sufferers similar to that of non-migraineurs: The Reykjavik Study. Cephalalgia. 2009;29:1301-10.

21. Di Napoli M, Schwanniger M, Cappelli R, et al. Evaluation of Creactive protein measurement for assessing the risk and prognosis in ischemic stroke: a statement for health care professionals from the CRP Pooling Project members. Stroke. 2005;36:1316-29.
22. Sentürk T, Cordan J, Bardan J, et al. Procalcitonin in patients with acute coronary syndrome: correlation with high-sensitive Creactive protein, prognosis, and severity of coronary artery disease. Acta Cardiol. 2007;62:135-41.

23. Lassen LH, Jacobsen VB, Haderslev PA, et al. Involvement of calcitonin gene-related peptide in migraine: regional cerebral blood flow and blood flow velocity in migraine patients. J Headache Pain. 2008;9:151-7.

24. Lassen LH, Haderslev PA, Jacobsen VB, Iversen HK, Sperling B, Olesen J. CGRP may play a causative role in migraine. Cephalalgia. 2002;22:54-61.

25. Becker KL, Nylen ES, White JC, Muller B, Snider RH Jr. Procalcitonin and the calcitonin gene family of peptides in inflammation, infection and sepsis: a journey from calcitonin back to its precursors. J Clin Endocrinol Metabol. 2004;84: 1512-25.

26. Schneider HG, Lam QT. Procalcitonin for the clinical laboratory: a review. Pathology. 2007;39(4):383-90. 